\title{
Distance Learning in Elementary School Classrooms: An Emerging Framework for Contemporary Practice
}

\section{Gulnara M. Burdina}

Elabuga Institute (branch) of Kazan Federal University, Russia, gburdina@yahoo.com

\section{Irina E. Krapotkina}

Elabuga Institute (branch) of Kazan Federal University, Russia, ikrapotkina@mail.ru

\section{Liliya G. Nasyrova}

Elabuga Institute (branch) of Kazan Federal University, Russia, nasirovalg1@yandex.ru

When new advanced technologies showed up in the market, teacher's role in distance learning step further in its path to change. Teachers often fail to find what their purpose of acting among technologies is and what the method for teaching elementary school students online would be right. Considering student's need in communication with a teacher to be at the core of learning as it is, we define what shape the new curricula will take from year to year. This research is a two-stage experiment with two additional surveys that included 430 students aged 8-9 years from across the Republic of Tatarstan. Students need not only facilitators to get better grades, but also a teacher mentoring them. Student-teacher communication can help students to raise their academic performance and motivation. Questions asked by students in time reduce the number of those who cannot reach their grade level from $9 \%$ to $0 \%$, and increase the number of A-level students from $11 \%$ to 26\%. The results confirm that the on-the-spot teaching method should be introduced into the e-learning curricula for primary school so that it provides a more intimate communication between the student and the teacher during classes. Results can be put into practical context to create new e-learning courses for public and private schools.

Keywords: elementary education, distance learning, learning technologies, online education, e-learning

\section{INTRODUCTION}

As long as the changes cover all spheres of a person's life, education tends to lag behind in development (Johnson, 2018). Teaching methods simply do not keep up with the world. This phenomenon is most evident in the field of primary education (Altan \& Karalar, 2018). There are several reasons behind this problem. Firstly, the pace of

Citation: Burdina, M.G., Krapotkina, I. E., \& Nasyrova, L. G. (2019). Distance Learning in Elementary School Classrooms: An Emerging Framework for Contemporary Practice. International Journal of Instruction, 12(1), 1-16. https://doi.org/10.29333/iji.2019.1211a 
development is more rapid against the slow pace of methods application. Secondly, the approach to assess the information needs and knowledge of elementary students is wrong. Knowledge and skills that teachers have are out of date. Moreover, in some regions and countries, socio-economic development is at the low level (Oliver et al., 2010).

Students far and wide change their life targets. If the previous generation was called the homuter society (homo + computer), then modern students fit the category of mobile homuter society, since they regard mobile phones, ipods and tablets as the main channel for communication and learning (Rammert, 2012). The pace that technologies took to spread among us has led to the so-called virtualization (Huda et al., 2017). Virtualization is a process when the basic social needs of an individual are met via computers and mobile devices. It generates a completely new phenomenon - cyber socialization (Gaol \& Hutagalung, 2017). In such a climate, elementary school teachers have to deal with early virtualization, as students start delving into a virtual world in the preschool period (Opperman, 2016). This becomes a problem because students are forced to change their perception paradigm from a virtual to the real one. Since approaches to preschool education differ from one another, so as the standards of family education, students start school with unequal background. If in one case, parents were fine with virtualization and went for it as for a part of early development, then other parents considered gadgets as an unacceptable element of education (Tcai \& Yeh, 2016). In response to cyber socialization and rising significance of computers and mobile devices, more and more schools around the world introduce computer literacy as a separate course that begins since the first days of education $(\mathrm{Ng}, 2010)$. Moreover, the current pace of virtualization allows finding new teaching approaches and methods. Distance learning is one of these approaches that is the most important one.

Distance learning is a learning system when the teacher and student are separated geographically or technologically (Rogers, 2009). Distance learning does not imply a completely remote mode. It is often combined with full-time activities that require classroom presence (Rogers, 2009). The rapid technology development, however, allows taking this necessity online. Distance learning has been actively integrated into the US education system from the very start (through to 1990s). This tool allowed delivering education to those groups of people, who could not attend full-time classes for obvious reasons: students with disabilities, health problems, and students, who lived far from school and had no opportunity to attend it on a daily basis. However, the number of programs was limited back then, and the process had no system behind it (Cavanaugh, 2009).

These days, many States have a Distance Learning Development Program that allows experimenting with the way the information is presented, as well as with the interaction options. The list of major tools still has the Internet, specialized programs and video records of lessons and courses on it (Cavanaugh \& Blomeyer, 2007).

When we argue on the significance of distance learning, we refer not only to the system itself, but also to the method of communication applied by the teacher and his/her student. At this point, we have two types of tools to distinguish, more specifically 
synchronous and asynchronous communication tools. Synchronous communication is a real-time way for students and teachers to interact at the same time, while asynchronous communication implies interaction in delayed time because of bandwidth gaps that arise from contextual issues. In other words, students have more time for feedback and can file their answers when teachers are off-line (Branon \& Essex, 2001). Distance learning, however, leaves no room for non-verbal communication because it technically achievable only through a videoconference (Neill, 2017). At this point, communication and understanding level down, given that non-verbal signs are considered as an important part of language and reasoning (Kopcha \& Alger, 2014).

Another important aspect of communication is a channel between the teacher and the parent/tutor responsible for the child. Face-to-face communication is currently considered more effective than its virtual alternative. It allows both participants in the conversation to experience a greater level of trust and understanding between each other. Thus, if real-life communication can be done for any geographical or other reasons, then benefits from communication are least (Al Ghamdi, Samarji \& Watt, 2016). The same is true for student-student communication. If some of the learning material is taught on a real time basis, then students get more motivated to remember things because they feel like the teacher is standing right beside them (Horzum, 2015).

Teacher's role remains important even if learning goes online, as he/she continues to act as a mentor (even if the child has a tutor of his own) (Hernández-García, GonzálezGonzález, 2015). Even those elementary students, who have been learning at distance from the first day at school, have a psychological need to rely on teacher's authority. If the tutor acts totally as a teacher (and if so, then the school only provides the program), then he/she fairly becomes a mentor to the student. Virtual communication between the student and his/her teacher requires a strict line between them so that the child realizes the authority his/her teacher possesses (Imlawi, Gregg \& Karimi, 2015).

Despite the small differences in organization and approach to distance learning, the world experiences are quite similar in general terms. This allows us outlining the main features and advantages of distance learning. Distance learning allows students, who do not have the opportunity to attend school for obvious reasons, to get content knowledge at full scale. Distance learning can follow both a special program and a general school curriculum. Distance learning requires the student and the teacher to have a sufficient level of computer proficiency. Any student must have a tutor to learn at distance. In most cases, tutor's role is played by a parent, who also goes between the student and the teacher. Distance learning can take a hybrid shape (include some elements of full-time education) or be completely virtual. Distance learning should have a good legal framework behind it.

Distance learning is not just the only opportunity for some groups of students. In cases when the student is not comfortable with group lessons, online learning contributes to greater interest in learning and to better performance (Ma \& Wei, 2016). Student's need in communication with the teacher sets a shape for new curricula to take. Thus, the purpose of this study is to develop a versatile distance-learning program for elementary school as well as to test its effectiveness by experiment. 


\section{METHOD}

\section{Research design}

This research is a two-stage experiment that implies diagnostic and formative stages. Our advisor was the Head of the Secondary School No. 34 (Kazan, Volga Region).

At the diagnostic stage of the experiment, teachers have been following the school curriculum on a distance basis for 3 months. Students were assessed at its end. At the second stage (another 3 months), teachers interacted with students during each lesson, thereby replacing a standard lesson that implies self-directed work with live communication and videoconferences explaining the material. The second assessment was conducted at the end of these 3 months.

\section{Participants and sampling technique}

We picked 430 respondents out of 730 students aged 8-9, who took distance courses across 29 different schools of the Republic of Tatarstan. Sampling was carried out with regard to the following factors:

- computer skills (skills of handling a tablet, a phone, the Internet);

- continuous access to the network during class time (8.30-13.30);

- technical opportunity to contact the teacher;

- readiness to undergo additional assessment during the experiment.

Official written permissions were received from school administrations and from parents of each student to participate in the experiment. More details on the respondents are in Table 1.

Table 1

Participants of the Experiment on Interaction in Distance Education (Republic of Tatarstan)

\begin{tabular}{llllll}
\hline & $\begin{array}{l}\text { Total Number } \\
\text { Participants }\end{array}$ & $\begin{array}{l}\text { Females } \\
\text { aged 8 }\end{array}$ & $\begin{array}{l}\text { Males } \\
\text { aged 8 }\end{array}$ & $\begin{array}{l}\text { Females } \\
\text { aged 9 }\end{array}$ & $\begin{array}{l}\text { Males } \\
\text { aged 9 }\end{array}$ \\
\hline In figures & 430 & 81 & 95 & 117 & 137 \\
\hline In \% & $100 \%$ & $18.84 \%$ & $22.09 \%$ & $27.21 \%$ & $31.86 \%$ \\
\hline
\end{tabular}

The statistical error is $1.75 \%$ (response rate is $97 \%$ ) (Table 2). The experiment was carried out under the support of 43 elementary school teachers, Kazan. They were selected by experience in distance teaching (at least 3 years to pass). Each teacher took a random group of 10 students.

Participants were graded at international ECTS scale (Table 2).

Table 2

ECTS Grading Scale

\begin{tabular}{ll}
\hline Grade & Definition \\
\hline A & Outstanding performance without errors \\
\hline B & Above the average standard but with minor errors \\
\hline C & Generally sound work with some errors \\
\hline D & Fair but with significant shortcomings \\
\hline E & Performance meets the minimum criteria \\
\hline
\end{tabular}




\section{The Procedure of the Implementation}

At the diagnostic stage, students continued to learn under the program established by their schools. This gave the participants a stress free course to continue their learning practice as normal.

More details on the distance learning class schedule are in Table 3.

Table 3

Distance Learning Class Schedule Designed for the Diagnostic Stage

\begin{tabular}{ll}
\hline Time Period & Type of Activity \\
\hline 8.30 & Student emails the teacher to start the lesson \\
\hline $8.30-9.00$ & Student watches video materials introduced by the teacher within the course framework \\
\hline $9.00-9.15$ & Student does exercises attached to video materials independently \\
\hline $9.15-9.30$ & Break Time \\
\hline $9.30-10.15$ & Student goes through the new material independently \\
\hline $10.15-10.30$ & Break Time \\
\hline $10.30-10.45$ & Student watches video materials introduced by the teacher within the course framework \\
\hline $10.45-11.15$ & Student does exercises attached to video materials independently \\
\hline $11.15-11.30$ & Break Time \\
\hline $11.30-12.15$ & Student goes through the new material independently \\
\hline $12.15-12.30$ & Break Time \\
\hline $12.30-13.00$ & Student contact the teacher online to discuss the material \\
\hline Negotiable & Individual communication with the teacher if necessary \\
\hline
\end{tabular}

It turned to our attention that students have only 30 minutes a day to speak to their teacher. This time may not be enough to get necessary answers, especially if questions to ask are misleading. In the light of the above factor, the schedule was modified in the second stage (Table 4).

Table 4

Distance Learning Class Schedule Designed for the Formative Stage

\begin{tabular}{ll}
\hline Time Period & Type of Activity \\
\hline 8.30 & $\begin{array}{l}\text { Students and their teacher connect to the Internet and let know about their attendance via } \\
\text { the chat room }\end{array}$ \\
\hline $9.35-9.05$ & Students watch video materials introduced by the teacher within the course framework \\
\hline $9.15-9.30$ & Material is discussed via the chat room \\
\hline $9.30-10.00$ & $\begin{array}{l}\text { Treak Time } \\
\text { questions if necessary }\end{array}$ \\
\hline $10.00-10.15$ & Students do exercises independently \\
\hline $10.15-10.30$ & Break Time \\
\hline $10.30-10.45$ & Student goes through the new material independently \\
\hline $10.45-11.00$ & Students discuss the material with the teacher via the chat room \\
\hline $11.00-11.15$ & Students do exercises independently \\
\hline $11.15-11.30$ & Break Time \\
\hline $12.00-12.00$ & $\begin{array}{l}\text { Teacher delivers new info to the group via online translation. Students can text to ask } \\
\text { questions if necessary }\end{array}$ \\
\hline $12.15-12.30$ & Students do exercises independently \\
\hline $12.30-13.00$ & Break Time \\
\hline
\end{tabular}


To organize any changes in the learning process, we took the advantage of the messenger chat room features, as well as the advantage of a live streaming platform. Other than that, all learning materials and the program remained the same. The main holdback of this experiment was the complete dependence of such a learning process on technical tools. Offline student could miss the whole day. Moreover, the effect of teacher's teaching style on the outcomes could not be traced.

\section{FINDINGS}

The experiment was to demonstrate how crucial the student-teacher communication during classes is for the information to assimilate better. We were also expecting to link the student's progress with the changes in teaching methodology. Research results revealed that communication with the teacher and other students positively affects student's progress, assimilation rates and level of motivation. First assessment showed that only few students reach the highest standard if information is delivered livestream (Figure 1).

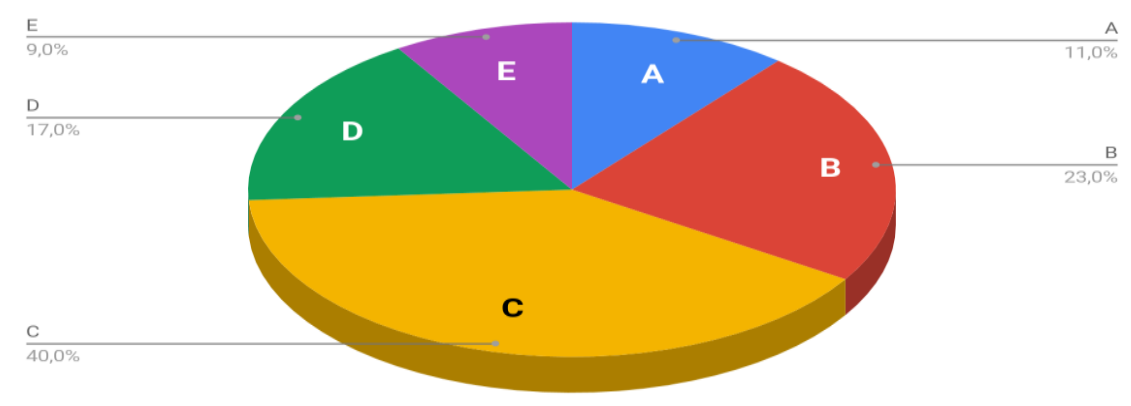

Figure 1

Assessment Results (Diagnostic Stage)

The number of A-level and E-level students was very much the same $-11 \%$ and $9 \%$, respectively. At the same time, the majority of students got C (40\%). Another $23 \%$ gained $\mathrm{B}$ and $17 \% \mathrm{D}$. We stress that all participants received the same learning materials in the one language. Therefore, we decided to put a survey to determine the reason standing behind this variation.

Participants were asked to answer three simple questions:

How many lessons a day does the tutor boost?

a) All on the agenda;

b) One or two;

c) None.

2. How often do you hit your teacher with questions after classes?

a) Every day; 
b) Once or twice a week;

c) Not even once.

3. Do you go for extras?

a) Always;

b) Sometimes;

c) Never done that.

The survey was put online by teachers among their distance groups. Of the 430 respondents, 378 completed the questionnaire, so the statistical error is less than $2 \%$. The results showed that in the group with D-level and E-level results, students had little chat with the teacher (Figure 2).

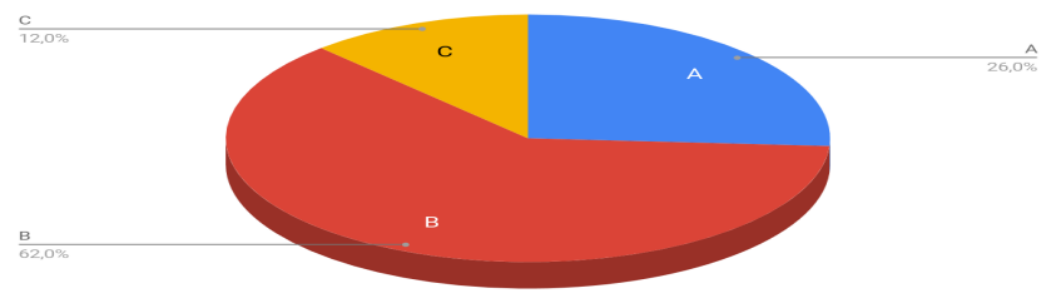

Figure 2

How Often Do You Hit Your Teacher With Questions After Classes? (groups with Dlevel and E-level results)

Considering that, we assume that high achievements and interest in learning arise from close interaction between the student and his/her teacher. High grades (A and B) received students taking extracurricular classes: $68 \%$ responded that they were taking extras on a constant basis, and only $13 \%$ - that they did no extra work at all (Figure 3).

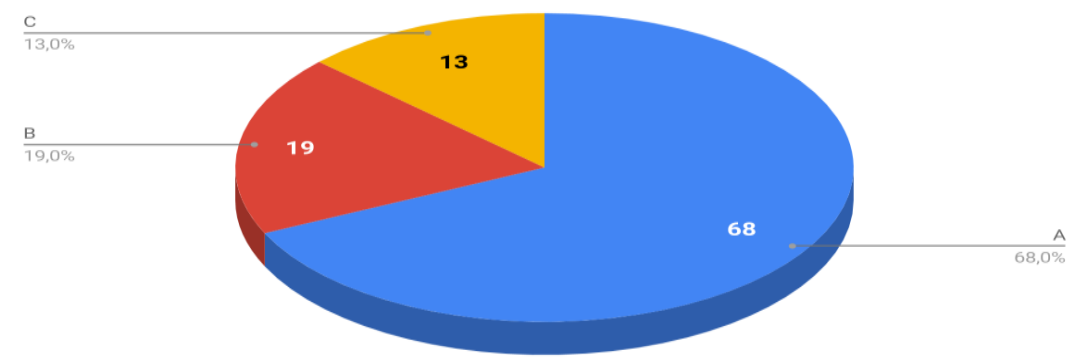

Figure 3

Do You Go For Extras?

International Journal of Instruction, January2019 • Vol.12, No.1 
This suggests that students perform well in spite of the curriculum, not because of it, since those of them, who want to get high grades, have to spend extra time to learn the information. It will be fair to note that not all students have financial and physical opportunities for extra classes. Besides, this need for electives may indicate that students simply do not process the information during class time either because of the quality of learning materials, or because of how they are presented.

Another reason for them to take extra classes is the initiative of their parents or the tutor, so we end here with $68 \%$ of children taking extras, but only $26 \%$ of them really need to. The rate of extracurricular attendance is so high also because parents give little credit to the official education programs. In general terms, the survey confirmed that a lack of communication with the teacher may be one of the reasons behind the poor distance outcomes. Therefore, the second stage was as originally planned.

At stage 2, 25 participants left the experiment, so the statistical error is $1.83 \%$. The formative stage lasted as long as the diagnostic stage -3 months. Final assessment took E-level students from the list. At the same time, D-level students thinned twice as down - to $8 \%$ (Figure 4).

Points scored

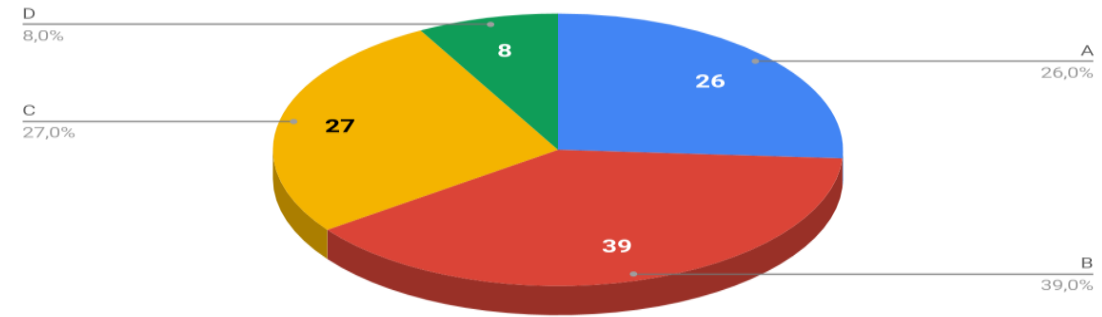

Figure 4

Assessment Results (Formative Stage)

It is striking that the number of A-level and B-level students increased on the back of narrowed range of $\mathrm{C}$-level performers. More details on the difference in results between stages are in Figure 5. 


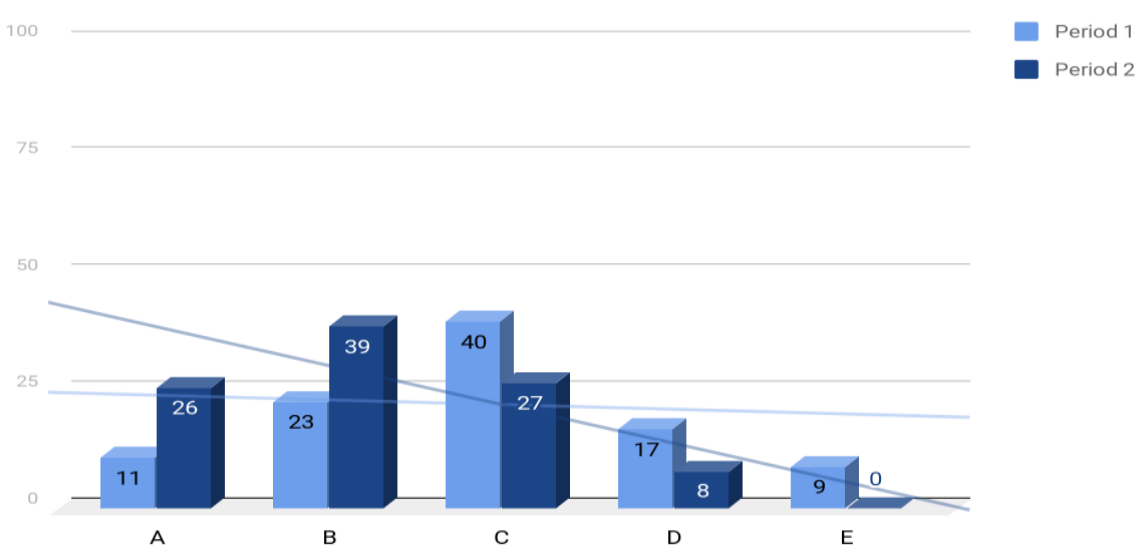

Figure 5

Comparative Case Study of Stages 1 and 2

It should also be noted that some students, who gained E, managed to gain D at the end of the second stage, while some of them even reached $\mathrm{C}$ level. The rise indicates that applied method allows students to absorb the knowledge better. The even E-level range also indicates a motivation boost, or an effect of online communication via chat rooms, as student-teacher communication alone does not allow the child to compare his/her own achievements and get motivated by the result. At the end of the second stage, teachers put a final online survey in their groups. Students were informed that their answers would be sent directly to the experiment providers, so that children could feel safe that their teacher will not see the answers.

The questionnaire contained three items:

Did you enjoy the lessons at which you could ask questions to the teacher?
a) Yes, I did;
b) No, I did not;
c) I think nothing of them.

Did you enjoy the lessons with online disputes as part of them?
a) Yes, I did;
b) No, I did not;
c) I think nothing of them.

Would you like to continue the mode you were learning at these 3 months?
a) Yes, I would;
b) No, I would not;
c) It will make no difference to me.

All 405 respondents filled in and sent an electronic form. The majority answered affirmatively to all three questions $(85 \%, 91 \%$ and $92 \%$ respectively). The answer b) was never picked (Figure 6). 


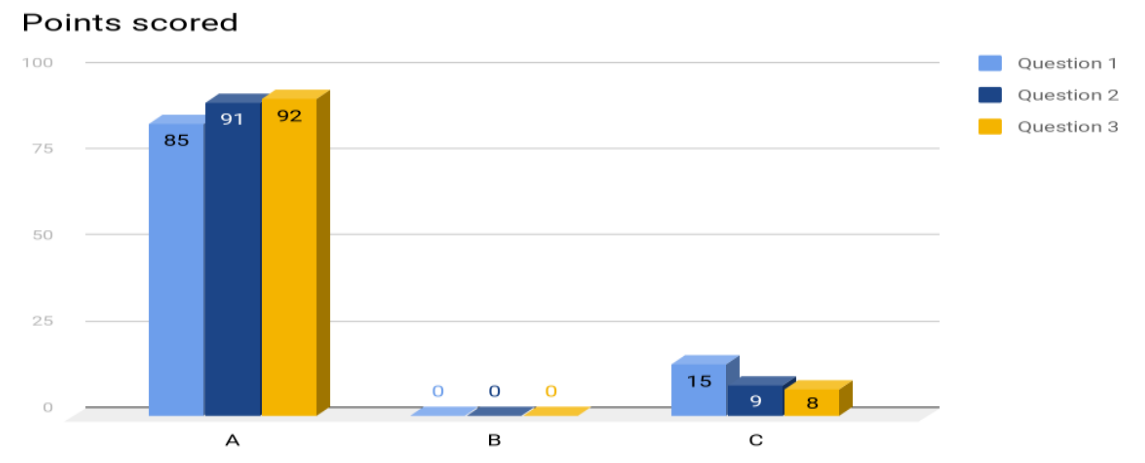

Figure 6

Distribution of Answers

High ratio of a) answers in the feedback is an evidence on the need students have for synchronous communication with their teacher, not only from the perspective of better understanding of what was presented, but also because it adds to the process of shaping a psychological readiness to be engaged in learning. Online learning also has a special room for interaction with virtual classmates. Communication via group allows absorbing new material better and rises a sense of being part of something, which is also one of those features attributed to school education. No b) answers can also indicate high motivation and psychological readiness to improve oneself. The experiment and surveys show that the direct effect on student performance has not only a livestream or an onspot strategy of material delivery, but also the opportunity to discuss new material with other students.

Communication is the major prerequisite for raising the outcomes and interest in learning at distance. Alongside thins, the reason behind low performance can also be a weak control over daily activity. It is believed that the learning process must be controlled by a tutor (or any relative), who helps the child to go through the course. At the same time, results show that the greatest effect will be achieved if a teacher takes charge of the class. In this case, the solution may be such course program design that will provide for daily student-teacher interaction during classes. The less is the amount of independent work a child does the less is the chance that he/she will miss the material.

Another link giving a boost to the learning process management can be the online communication between classmates. This allows the teacher be aware of the involvement scale of each student. As for students, online communication is also a path of cyber socialization. Thus, distance teaching is more than just facilitatorship. Mentoring here as important as in traditional full-time education whereas cyber socialization of a student among equals has a positive impact on motivation and progress.

In this case, introduced methodology will take the following shape (Figure 7). 


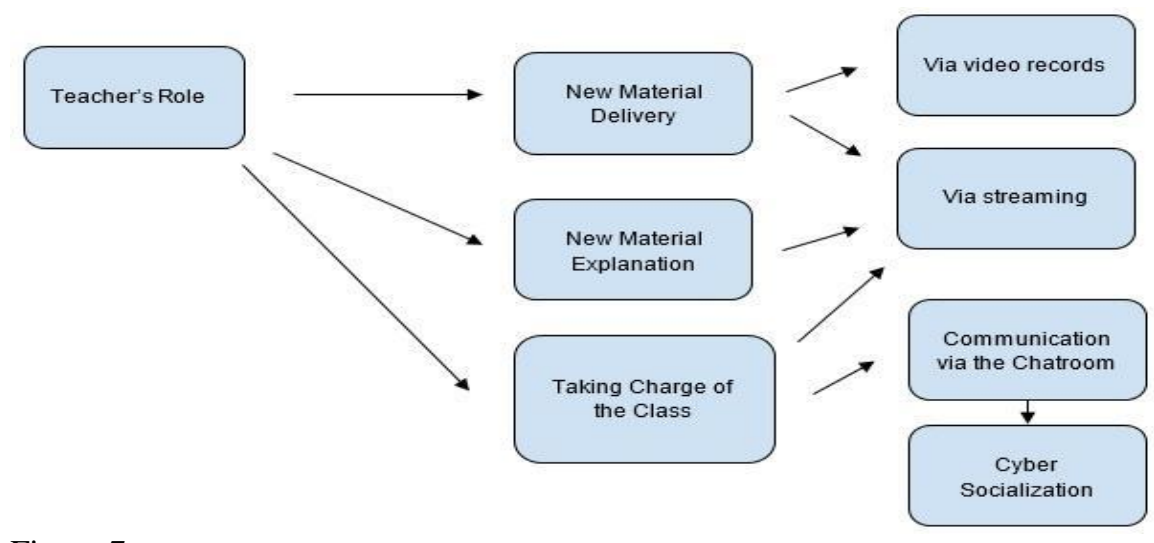

Figure 7

Designed Pattern of Teaching and Learning

The distance-on-spot teaching technique designed for the course is recommended for integration into the curricula of elementary schools.

\section{DISCUSSION}

Scandinavian countries are huge platform for experiments in the field of distance learning (Keegan, 2003). Online education there plays an important role, as it provides education for children with special characteristics of development. However, even with distance courses, Scandinavian educational establishments expect that students will attend classes themselves or with a tutor. This is part of their socialization (Nyyssölä \& Hämäläinen, 2011). Students living far or having no opportunity to attend full-time classes can do with a hundred-per-cent digital learning system and knowledge assessment (Moore \& Kearsley, 2011).

German universities and colleges allow distance students to accept diplomas remotely. However, elementary school students are required to undergo final testing in class (Keegan, 2013). In France, Spain and Belgium, similar principle applies to elementary school (Ordóñez de Pablos, 2014).

Yet, America holds its position of a successor in distance learning. Over 250.000 students get school education through an online course in private or public schools (Picciano \& Seaman, 2009). At the same time, 57\% of them prefer a virtual course, which implies communication during the class, while another $43 \%$ prefer to take courses, based on interactive video programs (Moore, 2013).

Education programs are usually designed by private virtual schools themselves. Public schools can implement programs already designed by other educational establishments or state education departments. Aside from them, there are many ready-made lesson plans and courses in public domain (most commonly on municipal government websites) (Maeroff, 2015). 
Some American projects in the field of distance learning have a common ground that allows combining virtual education with traditional full-time modes (hybrid education). In 31 States, there are online schools, including elementary ones. They are either under jurisdiction of a real school, or are virtual and funded through the state budget (Watson, 2008). Such practice is exemplified in the Green Wood Elementary School, Alabama. Distance learning here is a separate department. Teachers teaching ordinary classes also guide the distance students. However, their schedule is tuned to their job in the virtual sphere. The school, supported by the state, designs e-learning programs and own materials applying a state grant (Welch, 2015).

In the UK, virtual schools carry not only an educational function, but also help to explore this new area. They apply another approach to process organization - online learning is not tied to traditional modes and is regarded as an alternative (Latchem \& Jung, 2012). Notschool.net is one of the most striking projects in Britain. It offers not only an alternative to the school, but also collaboration with specialists in socialization and reintegration into society (Parsons, 2018). Aside from that, there is a psychologist working with children and their parents. This helps to correct and strengthen the child's motivation and psychological readiness.

In Europe, distance learning is usually defined as a school of external studies (Qayyum \& Zawacki-Richter, 2018). The state program for distance learning is designed to follow a regular full-time course. Besides, the student has to show up once in 2-4 weeks for consultations and assessment. There is an inclusive education program designed to socialize students, who are able to attend school once a week. This program provides for tutoring that must take place in face-to-face settings depending on child's condition. However, private virtual schools get more popular rather than state-owned ones (Keegan, 2013).

There are still several unresolved problems standing in the way of effective distance education. For example, teacher's role of a change is agent. Denmark research that involved 1.602 teachers from across 59 schools revealed the following trend. Teachers were divided into five groups by polling: teachers, who were ready to learn innovative methods; teachers, who felt critically about applying technology in schools; teachers, who had troubles with technology application; teachers, who were already applying technologies, be that time; teachers, who were unsure about technology application in class (Admiraal et al., 2017). At this point, the problem is that it is impossible to cast in stone the relationship between the effect of distance learning and student's further motivation, since this is about elementary school, where the child often does not have the opportunity to compare the full-time and distance modes (Keeagan, 2013).

Another barrier is the experimental status of most innovations in distance learning. These days, we cannot track the full cycle of virtual education (from elementary school to university admission) of at least one student, as most programs are often introduced for temporary use (Miller et al., 2014). In addition, the problem of closing the gap in student-teacher relationship is rarely discussed. In disregard of technology progress, teachers continue to play the role of a facilitator and cannot have full control over the student during the online session (Simonson, 2016). 
Defining the teacher's role in distance learning and his/her impact on its effectiveness remains one of the most important issues. Unfortunately, most successful discoveries made by foreign researchers are not applicable to Russian educational establishments for several reasons. Russian schools lack of high-quality infrastructure, anytime access to the Internet, legislative framework establishing private virtual schools as alternative establishments, and data on the teacher's distance teaching potential. At the same time, the optimal solution for Russian education system can involve the adoption of American experience at the level of education departments. Local authorities can launch online case programs based upon own capabilities (human resources, material and technical resources, etc).

\section{CONCLUSION}

Teachers often cannot find their place among technologies or the right method to teach elementary school students online. Allocating the needs of students through communication gives a direction for the new curricula to design.

The two-stage experiment conducted among 430 students of Kazan and suburb online schools shows that distance-learning curriculum of elementary schools requires amending, as students need not only facilitatorship to get better grades, but also a teacher mentoring them. Student-teacher communication can help students to raise their academic performance and motivation. Questions asked by students in time reduce the number of those who cannot reach their grade level from $9 \%$ to $0 \%$, and increase the number of A-level students from $11 \%$ to $26 \%$. Surveys revealed the relationship between the student's low performance and his/her rare attitude to ask teacher questions. In percentages, $62 \%$ of those graded below the average standard ( $D$ and $E$ ) ask questions no more often than 1-2 times a week. High grades (A and B), however, receive those students, who have more workload after classes $(68 \%)$, they do not learn better because of the quality of learning material or the style of its delivery.

A follow-up survey indicates that the lack of socialization is another important problem of distance learning. It can be solved through partial cyber socialization during the class (communication on the subject matter between the student and the group). As we recorded, $92 \%$ of respondents indicated that they would like to continue learning in a format when the student-teacher communication occurs directly during the lesson, but not after when it is allotted. Research results show that distance learning, as traditional full-time education, is no longer about education only. As long as the critical thinking skills of elementary school students are not high, so as their skills of problem solving and self-motivation, they need not only a home tutor to mentor them, but also a teacher. Otherwise, the curriculum will remain simply a set of meaningless information.

\section{REFERENCES}

Admiraal, W.; Louws, M.; Lockhorst, D.; Paas, T.; Buynsters, M.; Cviko, A.; ... \& van der Ven, F. (2017). Teachers in school-based technology innovations: A typology of their beliefs on teaching and technology. Computers \& Education, 114, 57-68. 
Al Ghamdi, A., Samarji, A., \& Watt, A. (2016). Essential considerations in distance education in KSA: Teacher immediacy in a virtual teaching and learning environment. International Journal of Information and Education Technology, 6(1), 17.

Altan, B. A. \& Karalar, H. (2018). How students digitally age: by gaining or losing? İlkögretim Online, 17(2).

Aphek, E. (2000). Children Tutoring Seniors at internet Skills: an Experiment Conducted at one Israeli Elementary School. In the context of Distance Education, 48.

Bernard, R. M.; Abrami, P. C.; Lou, Y.; Borokhovski, E.; Wade, A.; Wozney, L.; ... \& Huang, B. (2004). How does distance education compare with classroom instruction? A meta-analysis of the empirical literature. Review of educational research, 74(3), 379439.

Blackstock, A. \& Straight, N. (2015). Interdisciplinary Approaches to Distance Teaching: Connecting Classrooms in Theory and Practice. Routledge.

Bork, A. \& Gunnarsdottir, S. (2012). Tutorial Distance Learning: Rebuilding Our Educational System. Springer Science \& Business Media.

Branon, R. F., \& Essex, C. (2001). Synchronous and asynchronous communication tools in distance education. TechTrends, 45(1), 36-36.

Erdosne, T.E.; Klahr, D.; Chen, Z. (2000). Bridging research and practice: A cognitively based classroom intervention for teaching experimentation skills to elementary school children. Cognition and instruction, 18(4), 423-459.

Ertikanto, C. (2017). Development and Evaluation of a Model-Supported Scientific Inquiry Training Program for Elementary Teachers in Indonesia. International Journal of Instruction, 10(3), 93-108.

Gaol, F. L. \& Hutagalung, F. D. (2017). Social Interactions and Networking in Cyber Society. Springer.

Hernández-García, Á., González-González, I., Jiménez-Zarco, A. I., \& Chaparro-Peláez, J. (2015). Applying social learning analytics to message boards in online distance learning: A case study. Computers in Human Behavior, 47, 68-80.

Horzum, M. B. (2015). Interaction, Structure, Social Presence, and Satisfaction in Online Learning. Eurasia Journal of Mathematics, Science \& Technology Education, 11(3), 505-512.

Huda, M.; Jasmi, K. A.; Basiron, B.; Hehsan, A.; Gassama, S. K. (2017). Empowering children with adaptive technology skills: careful engagement in the digital information age. International Electronic Journal of Elementary Education, 9(3), 693-708.

Imlawi, J., Gregg, D., \& Karimi, J. (2015). Student engagement in course-based social networks: The impact of instructor credibility and use of communication. Computers \& Education, 88, 84-96. 
Johnson, J. (2018). Building Effective Professional Development in Elementary School: Designing a Path for Excellent Teaching. Routledge.

Keegan, D. (2003). Distance Training: Taking Stock at a Time of Change. Routledge.

Keegan, D. (2013). Otto Peters on Distance Education: The Industrialization of Teaching and Learning. Routledge.

Kilic, A. P. D. G. B. (2001). Descriptive Study of Student's Attitudes Toward Communicating Computers in an Elementary Science Methods Course. Turkish Online Journal of Distance Education, 2(1).

Koç, E. M. (2016). A general investigation of the in-service training of English language teachers at elementary schools in Turkey. International electronic journal of elementary education, 8(3), 455.

Kopcha, T. J., \& Alger, C. (2014). Student teacher communication and performance during a clinical experience supported by a technology-enhanced cognitive apprenticeship. Computers \& Education, 72, 48-58.

Latchem, C., \& Jung, I. (2012). Quality assurance and accreditation in distance education and e-Learning: Models, policies and research. Routledge.

Ma, M. Y. \& Wei, C. C. (2016). A comparative study of children's concentration performance on picture books: age, gender, and media forms. Interactive Learning Environments, 24(8), 1922-1937.

Maeroff, G. I. (2015). A Classroom of One: How Online Learning Is Changing our Schools and Colleges. St. Martin's Press.

Moore, M. G. (2013). Handbook of Distance Education. Routledge.

Moore, M.G. \& Kearsley, G (2011). Distance Education: A Systems View of Online Learning. Cengage Learning.

Nyyssölä, K. \& Hämäläinen, K. (2011). Lifelong Learning in Finland: The Extent to which Vocational Education and Training Policy is Nurturing Lifelong Learning in Finland. Office for Official Publications of the European Communities.

Oliver, K.; Kellogg, S.; Townsend, L.; Brady, K. (2010). Needs of elementary and middle school teachers developing online courses for a virtual school. Distance Education, 31(1), 55-75.

Ordóñez de Pablos, P. (2014). Assessing the Role of Mobile Technologies and Distance Learning in Higher Education. IGI Global.

Parsons, C. (2018). Looking for Strategic Alternatives to School Exclusion. In The Palgrave International Handbook of School Discipline, Surveillance, and Social Control (pp. 529-552). Palgrave Macmillan, Cham. 
Qayyum, A., \& Zawacki-Richter, O. (2018). Distance Education in Australia, Europe and the Americas. In Open and Distance Education in Australia, Europe and the Americas (pp. 121-131). Springer, Singapore.

Rammert, W. (1996). Computer Use at Home-A Cultural Challenge to Technology Development. The Information Superhighway and Private Households. Physica-Verlag HD.

Rink, J. E. \& Hall, T. J. (2008). Research on effective teaching in elementary school physical education. The Elementary School Journal, 108(3), 207-218.

Rogers, P. L. (2009). Encyclopedia of Distance Learning, Second Edition. Idea Group Inc (IGI).

Sahlin, J. S.; Tsertsidis, A.; Islam, M. S. (2017). Usages and impacts of the integration of information and communication technologies (ICTs) in elementary classrooms: case study of Swedish municipality schools. Interactive Learning Environments, 25(5), 561579.

Setzer, J. C. \& Lewis, L. (2005). Distance Education Courses for Public Elementary and Secondary School Students. 2002-Tab. NCES 2005-010. US Department of Education.

Sun, Z.; Yao, X.; You, J.; Du, W.; Luo, L. (2018). Detecting the correlation between mobile learning behavior and personal characteristics among elementary school students. Interactive Learning Environments, 1-16.

Tuncer, M. \& Tanaş, R. (2011). The Evaluation of Academicians' Views on Distance Education Programs (The Samples of Frat and Tunceli Universities). Elementary Education Online, 10(2), 776-784.

Turgut, S. \& Temur, Ö. D. (2017). The Effect of Game-Assisted Mathematics Education on Academic Achievement in Turkey: A Meta-Analysis Study. International Electronic Journal of Elementary Education, 10(2), 195-206.

Watson, J. (2008). Blended Learning: The Convergence of Online and Face-to-Face Education. Promising Practices in Online Learning. North American Council for Online Learning.

Welch, A. (2015). The Role of Primary Students and Parents in Virtual School. Distance Learning, 12 (2), 33-38.

Wu, W. C. V.; Wang, R. J.; Chen, N. S. (2015). Instructional design using an in-house built teaching assistant robot to enhance elementary school English-as-a-foreignlanguage learning. Interactive Learning Environments, 23(6), 696-714. 